\title{
ANALISIS TRIWULANAN: \\ PERKEMBANGAN MONETER, PERBANKAN \\ DAN SISTEM PEMBAYARAN \\ TRIWULAN IV - 2013
}

Tim Penulis Laporan Triwulanan, Bank Indonesia

Pertumbuhan ekonomi Indonesia triwulan IV 2013 lebih baik dari perkiraan Bank Indonesia disertai dengan struktur yang lebih berimbang. Pertumbuhan ekonomi mengalami peningkatan dari 5,63\% pada triwulan III 2013, menjadi 5,72\% pada triwulan IV 2013 ini (yoy). Hal ini ditopang oleh membaiknya ekspor riil sejalan dengan kenaikan permintaan mitra dagang negara-negara maju. Pada sisi lain, pertumbuhan permintaan domestik mengalami pertumbuhan yang moderat, ditandai oleh melambatnya konsumsi rumah tangga dan investasi, khususnya investasi non-bangunan. Dengan perkembangan ini, pertumbuhan ekonomi Indonesia untuk keseluruhan tahun 2013 tercatat sebesar 5,78\%.

Ekspor yang membaik mendorong penurunan defisit transaksi berjalan secara signifikan dan menopang perbaikan kinerja Neraca Pembayaran Indonesia (NPI) triwulan IV 2013. Defisit transaksi berjalan triwulan IV 2013 menurun cukup tajam menjadi 1,98\% dari PDB, jauh lebih rendah dari defisit transaksi berjalan pada triwulan III 2013 sebesar 3,85\%. Kenaikan ekspor didukung oleh kenaikan ekspor manufaktur sejalan meningkatnya permintaan dari AS dan Jepang, disamping peningkatan ekspor sumber daya alam terkait dengan antisipasi pemberlakuan UU Minerba'. Pada sisi lain, penurunan defisit transaksi berjalan juga dipengaruhi oleh penurunan impor sejalan pertumbuhan moderat pada permintaan domestik.

Perbaikan NPI triwulan IV 2013 juga ditopang peningkatan surplus transaksi modal finansial bersumber dari penarikan pinjaman luar negeri korporasi, penarikan simpanan bank domestik di luar negeri, dan arus masuk Penanaman Modal Asing Langsung yang tetap stabil. Bank Indonesia memperkirakan penguatan NPI berlanjut pada 2014 ditopang prospek defisit transaksi berjalan yang menurun serta surplus transaksi modal dan finansial yang meningkat. Pada Desember 2013, cadangan devisa Indonesia meningkat menjadi 99,4 miliar dolar AS atau setara dengan 5,4 bulan impor dan pembayaran utang luar negeri pemerintah, di atas standar kecukupan internasional sekitar 3 bulan impor.

Tekanan pelemahan terhadap rupiah sedikit mereda pada triwulan IV 2013. Perkembangan ini dipengaruhi oleh membaiknya kinerja NPI triwulan IV 2013 dan berbagai respons yang ditempuh oleh Bank Indonesia dan Pemerintah. Nilai tukar rupiah secara point to point pada

1 Undang-undang No.4 tahun 2009 tentangPertambangan Mineral dan Batubara. 
triwulan IV 2013 tercatat melemah 4,85\% (qtq), lebih rendah dibandingkan dengan depresiasi di triwulan III 2013 sebesar 14,29 (qtq). Secara rata-rata, pelemahan rupiah sedikit meningkat dari 8,18\% pada triwulan III 2013 menjadi 8,76\%. Sejalan dengan meredanya tekanan depresiasi tersebut, volatilitas rupiah juga berkurang.

Meski demikian, secara umum nilai tukar rupiah sepanjang tahun 2013 berada dalam tren melemah. Secara rata-rata, nilai tukar rupiah sepanjang tahun 2013 melemah sebesar 10,4\% dari Rp9.358 per dolar AS dari tahun 2012 menjadi Rp10.445 per dolar AS. Namun demikian, kondisi tersebut tetap dapat dikelola pada tingkat volatilitas yang relatif rendah, dan relatif lebih baik dibandingkan dengan sebagian negara Asia lainnya.

Respons kebijakan yang ditempuh Bank Indonesia dan koordinasi dengan Pemerintah berpengaruh positif pada menurunnya tekanan inflasi pada triwulan IV 2013. Setelah mengalami tekanan tinggi akibat gejolak pangan dan kenaikan BBM pada triwulan II dan III 2013, inflasi IHK pada triwulan IV 2013 tercatat jauh menurun yakni dari 4,08\% (qtq) atau 8,40\% (yoy) pada triwulan III 2013 menjadi 0,75\% (qtq) atau 8,38\% (yoy) pada triwulan IV 2013.

Penurunan tersebut terutama didorong oleh deflasi pada kelompok volatile food dan rendahnya inflasi pada kelompok administered prices pasca kenaikan harga BBM bersubsidi. Kelompok volatile food mencatat deflasi 0,58\% (qtq) pada triwulan IV 2013 dipengaruhi oleh membaiknya pasokan sejalan dengan berlangsungnya masa panen beberapa komoditas seperti bawang merah dan aneka cabai. Selain itu, adanya relaksasi kebijakan pengaturan impor hortikultura turut mendorong terjadinya perbaikan pasokan seperti pada komoditas bawang putih.

Sementara itu, inflasi administered prices tercatat rendah sebesar 1,40\% (qtq), jauh menurun dari triwulan III 2013 sebesar 8,94\% (qtq). Penurunan tajam tersebut sejalan dengan minimalnya kebijakan Pemerintah terkait penyesuaian harga barang-barang strategis setelah kenaikan harga BBM bersubsidi pada triwulan II 2013. Tekanan inflasi pada kelompok administered price pada triwulan IV 2013 hanya bersumber dari kenaikan tarif tenaga listrik (TTL) tahap IV pada November 2013 serta kenaikan Bahan Bakar Rumah Tangga (BBRT), khususnya LPG terkait penyesuaian tarif distribusi pada akhir tahun.

Sejalan dengan kedua kelompok komoditas di atas, inflasi intimenurunsebesar 2,59\% (qtq) menjadi 1,00\% (qtq). Penurunan tersebut dipengaruhi oleh belum kuatnya pengaruh lanjutan pelemahan nilai tukar terhadap inflasi, membaiknya ekspektasi inflasi paska kenaikan harga BBM bersubsidi, serta penurunan harga komoditas internasional non-pangan khususnya emas.

Penyesuaian ekonomi Indonesia yang terkendali, ditopang oleh stabilitas sistem keuangan yang tetap terjaga. Ketahanan industri perbankan tetap solid dengan risiko kredit yang terjaga, likuiditas dan kondisipasar yang baik, serta dukungan ketahanan modal yang masih kuat. 
Pertumbuhan kredit perbankan menurun dari 21,9\% pada November 2013 menjadi 21,4\% pada Desember 2013 (setara dengan 17,4\% jika efek depresiasi nilai tukar dinormalisasi). Hal ini sejalan dengan perlambatan pertumbuhan permintaan domestik dan kenaikan suku bunga. Bank Indonesia akan berkoordinasi dengan OJK untuk mengarahkan pertumbuhan kredit ke depan sejalan dengan pertumbuhan permintaan domestik yang moderat. Sementara itu, kinerja pasar saham pada Januari 2014 membaik ditandai dengan kenaikan IHSG. Perkembangan berbeda terlihat pada kinerja pasar obligasi pemerintah yang menurun tercermin pada kenaikan imbal hasil SBN.

Moderasi perekonomian domestik pada triwulan IV 2013 berdampak pada penurunan nilai transaksi sistem pembayaran. Nilai transaksi sistem pembayaran menurun sebesar Rp1.930 triliun (-5,31\%) menjadi Rp34.419,79 triliun dibandingkan dengan triwulan III 2013. Penurunan terutama terjadi pada transaksi sistem BI-RTGS yang disebabkan oleh menurunnya transaksi operasi moneter. Dari sisi volume, transaksi pada triwulan IV 2013 tetap meningkat terutama sebesar 94,7 juta transaksi atau meningkat 9,36\% dibandingkan dengan volume transaksi triwulan III 2013. Peningkatan volume terjadi pada semua jenis sistem pembayaran dengan kenaikan tertinggi pada transaksi APMK (Alat Pembayaran Menggunakan Kartu) khususnya kartu ATM dan kartu ATM/Debit yang umum digunakan masyarakat untuk mendukung aktivitas ekonomi di seputar hari libur. 
194 Buletin Ekonomi Moneter dan Perbankan, Januari 2014

Halaman ini sengaja dikosongkan 